\title{
The Achilles' heel of police reforms in Kenya
}

\author{
Douglas Lucas Kivoi, Casty Gatakaa Mbae \\ Policy Analyst, Kenya Institute for Public Policy and Research Analysis (KIPPRA), Nairobi, Kenya
}

\section{Email address:}

amatalo2000@yahoo.com(D. L. Kivoi),dkivoi@kippra.or.ke(D. L. Kivoi), njoroge33@yahoo.com(C. G. Mbae), cmbae@kippra.or.ke(C. G. Mbae)

\section{To cite this article:}

Douglas Lucas Kivoi, Casty Gatakaa Mbae. The Achilles' Heel of Police Reforms in Kenya. Social Sciences. Vol. 2, No. 6, 2013, pp. 189-194. doi: 10.11648/j.ss.20130206.13

\begin{abstract}
The genesis of policing in Kenya dates back to the pre-independence times. After independence, the constitution at that time had provisions for the establishment of a neutral police service. However that was just on paper because political leaders turned the police service into a political tool for suppressing and/or repressing political opponents, real or imagined. Thus the police impunity that was there during the colonial era was never eliminated from the service after Kenya got independence. Fifty years later, Kenya is still struggling with reforming its National Police Service which is fettered in many challenges among them corruption within its ranks, extra-judicial killings, limited and/or lack of professionalism, poor housing, lack of modern crime fighting equipments among numerous other challenges. The constitution promulgated in 2010 made demands for structural and welfare reforms to be carried out in the National Police Service. It is worth noting that the reforms anticipated in the police service are now way behind schedule. The culture of impunity in the police service has contributed to too many cases of insecurity, gross violation of human rights, mistrust by citizens and derailment of key achievements in democratic governance. It is thus evident that an overhaul of Kenya's police service is critical. This paper addresses some of the key challenges facing the National Police Service and gives some policy recommendations.
\end{abstract}

Keywords: Crime, Impunity, Mistrust, Police Service, Policing, Structural Reforms, Welfare Reforms

\section{Introduction}

Kenya's Vision 2030 lays emphasis on safety and security as crucial pillars for economic growth. Thus Vision 2030 and the constitution provide the basis for wide ranging police service reforms. Kenya inherited its security structure from the British colonial government which has remained the same for 50 years. Security of our country is critical if we are to realize our dream of being a middle income country by 2030 . Kenya Police's long and not so good history is characterized by inefficiency, corruption, disregard for rule of law, police brutality and blatant abuse of human rights. The Kenya Police which was formed in the $19^{\text {th }}$ century has always served as the state's principal organ of domination, repression, oppression, curtailing rather than enhancing the rights of citizens. At independence, the new government inherited the philosophy, structure and systems of the colonial police which successive governments have maintained to safeguard their grip on political power.

The government of Kenya is the midst of implementing ambitious reforms in the country as is enshrined in the constitution key among them, National Police Service reforms. The constitution stipulates various police reforms which if fully implemented will revamp the Police Service and address cases of police welfare, impunity by rogue officers, inefficiency and gross human rights violations. The establishment of the National Police Service Commission (NPSC) was a big step towards reforming this critical public sector charged with enforcing Rule of Law. It is worth noting that whereas some steps have been made in implementing police reforms; many critical reforms are yet to be made key among them the vetting of senior officers, comprehensive life insurance for all police officers, provision of security kits to all officers and the construction of a forensic laboratory for the Criminal Investigation Department (CID).

The slow progress of implementing the National Police Service reform agenda increases incidences of gross human rights violations and also limits the response and preparedness of the National Police Service in discharging its constitutional mandate to citizens. For example, the National Police Service was unable and/or incapable of preventing, managing and containing the 2007/2008 post election violence and in most cases police officers engaged in rampant human rights abuses, violations and excessive 
use of brutal force on unarmed civilians (Waki Report on Commission of Inquiry into 2007/2008 Post-Election Violence (CIPEV)). Also the National Police Service was caught napping during the Baragoi Massacre where over 40 officers lost their lives. There are also many glaring cases where terrorists have managed to slip into the city of Nairobi and commit atrocities on civilians without being detected by the National Police service officers. In May 2009, the government set up a Task force on Police Reforms chaired by a retired Judge Philip Ransley to make recommendations on necessary police reforms in the country. The task force came up with over 200 recommendations to be implemented in tandem with the constitution. Though the infamous 2007/2008 post election violence catalyzed the urgency for police reforms, cases of police officers abusing basic rights of citizens with impunity, extra judicial killings and police brutality have been documented by local and international agencies like Amnesty International among others.

The Kenya government has on numerous occasions admitted that the problem exists. In a report it submitted to the United Nations (UN) Human rights committee in July 2012, the government admitted that exra-judicial killings both by the Police and civilians of suspects remains a major problem in the country. The government went on to acknowledge that extra judicial killing is among the most serious human rights violations in the country. Thus the tainted image of the police service which originated from the historical roots of the Administration police and Kenya Police as tools for repression is not the only problem facing the National Police Service.

\section{National Police Service Legislation}

The National Police service Act 2011 merged the Kenya Police and Administration Police under one hierarchy and established the office of Inspector General of Police (IGP) who has authority over both two policing and law enforcing arms of the government. Article 41 of the National Police Service Act has placed limits on the amount of force which an officer is able to use when dealing with crime suspects, stating categorically that an officer may use "force and firearms, if and to such extent only as is extremely necessary."

The National Police Service Commission (NPSC) Act established a civilian board to oversee recruitment and appointments of police officers, review standards and qualifications, and receive complaints from the public and refer them to the Independent Policing Oversight Authority (IPOA) and other government entities for investigations and possible prosecution of offending officers whenever there is compelling evidence for doing so. The appointment of commissioners to the NPSC was delayed for several months due to political wrangling between politicians.

The Independent Policing Oversight Authority Act established Independent Policing Oversight Authority (IPOA) to handle cases of police misconduct and recommend disciplinary action to the National Police
Service Commission (NPSC). It is worth noting that this police oversight authority is yet to make any meaningful impact on policing in the country because fifty years after independence the country does not have a National Policing Policy and this civilian oversight authority seems not to be in a furry to draft it.

The Constitution is categorical and explicit on transparency and accountability from the National Police Service. The National Police Service command is under the command of the Inspector General of Police (IGP) who has authority over the Administration Police and Regular Police. The IGP is in turn deputized by two Deputy Inspector General's (DIG's), each from the two wings of the service. The IGP has security of tenure so as to prevent cases of interference from politicians and the Executive arm of government. This was to give the police service operational independence in enforcing the law impartially.

The NPSC is an independent constitutional commission whose key functions are to ensure that the National Police Service has the best management practices in recruitment, promotions and transfers and that they are done in an open and transparent manner. The constitution has laid greater emphasis on human rights and emphasized the need for the state through the National Police Service to respect and protect. This is in addition to international human rights law and treaties that Kenya is a signatory to. Even though Police officers have the right to use lethal force when enforcing Rule of Law, this right is controlled by international law and standards so as to avoid or minimize human rights violations. Nations are required to respect, protect the right to life, freedom and security of citizens living within their borders. Kenya is a signatory to the International Covenant on Civil and Political Rights (ICCPR), The Rome Statue that established the International Criminal Court (ICC) and African Charter on Human and Peoples' Rights (ACHPR) which have prohibited torture, cruelty and inhumane treatment of humans.

\section{Issues}

First, the level of public confidence in the National Police Service has been on the decline due to wanton cases of police brutality, impunity and malignant cases of corruption in the service. Kenyans have high hopes that the ongoing police reforms though at a snail pace will transform the Police Service from a "police force" into a service and people centered one that will respect the rights of citizens and be professional, transparent and accountable to the citizens. Civilian oversight is crucial for good management of the security sector. The creation of IPOA in the constitution is expected to bring on board the much needed monitoring, scrutiny and independence from political interference of the police service. IPOA has a constitutional mandate to receive complaints from the public regarding policing and also to conduct independent investigations and inquiries. If IPOA discharges its mandate in a forthright manner then it may help boost public 
confidence in the police service and stem political interference.

Secondly the police service operates on a thin budget which has stagnated since independence. Police officers lack basic equipments to fight crime like for instance, bullet proof vests, pocket radios, patrol vehicles, poor housing and a staff deficit. It is also critical to note that the Criminal Investigation Department (CID) does not have a forensic laboratory which would help in solving cases of rape and murder.

It has also been argued that the morale of the service is also very low due to an unsympathetic public and poor pay structures. Members of the public do not appreciate some of the good work done by police officers who most of the time put their lives on the chopping board to ensure that society is safe.

Also the training of these police officers is also put into question when one looks at how they handle crime scenes. Most of the time such scenes are never secured and if they are then handling of exhibits at the scene is most of the time compromised.

\section{Barriers to Implementing Police Reforms}

\subsection{Lack of Political Will}

Kenya like many other African countries is struggling with entrenched impunity in some of its governance institutions. Since independence the police service has been used as a tool of repression and oppression by the executive. Most of the times the police service has failed to comply with the law due to interference from politicians. There is lack of political will to have necessary legislation and properly fund the police service so as to ensure that it is in sync with globalization. There has been lack of political will to put in place necessary structures to address the lethargy, inefficiency and mistrust created as a result of long standing impunity in the police service because the police service in Kenya has since independence been used as a political tool and not as a public service institution.

Table 1. Likelihood of bribery - Kenya

\begin{tabular}{lll}
\hline Rank & Sector & Likelihood (\%) \\
\hline 1 & Police & 60.4 \\
2 & Land Services & 57.3 \\
3 & City and Local Councils & 42.8 \\
4 & Registry and Licensing Services & 41.5 \\
5 & Judiciary & 35.1 \\
6 & Medical Services & 34.3 \\
7 & Tax Services & 30.3 \\
8 & Provincial Administration & 28.0 \\
9 & Educational Institutions & 13.8 \\
10 & Utilities (Water, Electricity and Postal & 8.8 \\
\hline
\end{tabular}

Source: EABI (2012)

\subsection{Corruption}

The police service is seen as the most corrupt institution in Kenya. According to the East Africa Bribery Index (EABI) 2012, the National Police service still leads as the most corrupt public sector with the likelihood of bribery being at $60 \%$

There is greater need for efforts to be put in place to ensure that integrity within the National Police Service is restored. Corruption within the police service seems to be deeply entrenched and the government appears unable to contain it effectively especially in the traffic department and other key policing units. It is argued that some senior officers who are beneficiaries of graft in the police sector may be among those stalling reforms.

\subsection{Capacity Building and Infrastructure}

The National Police Service is most of the time underfunded. This has hampered its efforts to modernize itself and be up to task to match the sophisticated nature of crime and criminals. For example, the CID does not have a forensic laboratory to tackle sophisticated crime. Vehicle patrols and responses are bogged down by lack of serviceable patrol cars. This has led to weaker responses and coordination during incidences of crime and disasters requiring police response. Police officers do not have life insurance yet most of the time they find themselves in life threatening and dangerous situations when tackling crime or discharging their duty to citizens. Lack of life insurance has left many families of officers who die while on duty paupers with nothing to fall back to in form of compensation.

Also the police service lacks personnel in Information Communication Technology (ICT) to tackle crime using up to date technology in form, for example in cyber crime. This is an area that needs to be given serious consideration by the NPSC and the Ministry of Interior and National Coordination.

\subsection{Continued Police Impunity}

Lack of accountability in the National Police Service in form of prosecuting police officers who violate rights of citizens and officers who abuse their powers with impunity is another challenge that may hinder proper police reforms. There are many cases of police cover-ups, political manipulations and interference where perpetrators of crime go scot free when they ought to be prosecuted. In as much as IPOA ought to ensure such officers are prosecuted, the inertia of the Executive and Attorney General over cases of police brutality and human rights violations because the officers were acting on behalf of the state raises serious and legitimate concerns over their commitment to police reforms since it appears some police officers operate above the law with the blessing of the Executive. 


\subsection{Other Structural Challenges}

Kenyans are becoming more open and are willing to come forward to report cases of police brutality and excessive use of force. This reform has taken too much of a legalistic jargon yet there much that needs to be done in form of social change and development of proper policing policies. This reform focused on laws and legislation is extremely myopic and fails to appreciate and address real challenges facing the policing sector in the country.

It should be noted that a few years ago the government launched community policing to address the mistrust between the Police service and the citizens. The noble initiative fizzled out and in some areas it was misunderstood and taken as a government policy for communities to form vigilante groups and private militias. This has led to lynching of suspects and in some innocent people suspected of engaging in criminal activities were hacked to death. Some of this vigilante groups in turn have turned out to be extortionist gangs where local citizens are forced to part with money in form of "protection/security fee". Some of these vigilante criminal gangs later mutate and are used by politicians to settle political scores.

\section{Way Forward}

There is need for political leadership, The National Police Service and citizens to own police reforms. The government's primary control over the National Police Service should be the law and not politics. The government must require that there be conformity by the police to specific publicly announced policies arrived at through a process of consultation. The international community has also a critical role to play since there are great and vital lessons we can earn from them. The Ministry for Interior and Coordination of National Government ought to solicit for support and partnership with countries like United States of America (USA), Japan, United Kingdom, Sweden among others for critical cooperation and provision of equipment and technical expertise. These countries have some of the most effective police services in the world. This is so because no man is an island. The top most command in the National Police Service MUST genuinely embrace reforms to enable it offer top class services to citizens. Policing is a delicate sector which positively affects all sectors of the economy if it is properly handled or worse left to operate with impunity then we can kiss bye any economic growth. The performance of the National Police Service directly affects the judiciary. It is strange that the judiciary through the Judicial Service Commission (JSC) has positively embraced reforms whereas the National Police Service Commission is yet to even vet senior officers in the police service which ought to have been done by now. Given the long history of corruption in the Police Service, the vetting exercise will have helped root out senior officers who sanction corruption in the Police Service. Relying on long serving officers to carry out reform is limited by the capacity of some of these personnel to learn and apply new lessons and tactics in fighting crime and respecting human rights. It is also likely that some of these personnel may resist change and continue to adhere to the old way of transacting business. Also relying on new personnel has the consequence that at the point where the reform process is initiated the police service is constituted by inexperienced personnel who may not have had proper training especially in fighting cyber crime and other sophisticated crime networks. Therefore the delayed vetting of senior officers needs to be fast tracked and those implicated in corruption, human rights violations and police brutality be excluded. This then should be followed to a careful systematic approach to new recruitment based on development of the training systems and qualifications of recruits. Political leadership and serving senior police officers must support the need for depoliticizing the police service and carry out the necessary reforms as stipulated in the constitution.

The constitution of Kenya supports freedom of assembly and association. The National Police Service is tasked with supporting the holding of peaceful demonstrations and not lobbying tear gas canisters at peaceful demonstrators and brutalizing them. Thus unless the human rights framework is directly integrated with measures to support police reforms in improving performance of their duties while observing human rights standards, enforcement human rights may be seen as impeding police work by the serving police officers. The National Police Service should embrace support from the private sector in learning how basic policing is carried out in a way that respects basic rights of citizens. Senior Police commanders and supervisors should be held accountable in ensuring that those who violate rights of citizens are prosecuted. The National Police Service should only disperse political groups only when there is indubitable evidence that they are involved in violence, obstructing traffic, involvement in criminal acts and their actions must be subject to review by IPOA and a transparent and independent judicial commission. The National Police Service command hierarchy officers must commit themselves to the principle that the National Police Service will support democracy whilst remaining outside of it and not interfering with certain political groups considered to be anti-government under the pretence of national security. The National Police Service ought to desist from political interference or being used by the government to serve ruling political interests.

There is also need to promote learning and personal growth amongst police officers in interpersonal, intrapersonal and communication skills along with the practical knowledge on community policing, good practice in working with civilians to foster public trust in the service. It is an open secret that some if not most police officers do not have negotiation skills to deal with crowds. This too has to be addressed. The Executive ought in turn to ensure that it addresses questions of police personnel safety by providing basic equipments like bullet proof vests, patrol 
cars, improved pay, proper medical cover for officers and their families, modern housing infrastructure and above all a life insurance policy for all serving police officers in case they are injured or get killed in their line of duty. The caliber of personnel recruited must be of high academic standards so as to ensure that the National Police Service is not used as the last option for Kenyans who are looking for employment. This will instill professionalism in the service

Also it should be noted that Kenya does have a written policy on policing in the country. There is thus a need for a National Policing Policy to guide the operations and interactions between police officers and citizens. What is going on so far are what may be termed as "administrative Reforms" which do not essentially entail reforming the way policing is done in the country. It is paramount that the country gives the necessary attention and implementation of the Ransley Task force report so as to operationalise and entrench the new people centered police institutions that will ensure that the welfare of police officers are catered for and accountability in National Police Service.

Civil society groups also must play an invaluable and active role in Police reforms process by raising awareness, advocate and monitor the reform process to ensure that it is done the right way, conduct research and avail relevant policing information so as to achieve sustainable and successful long overdue police reforms in the country as opposed to the usual piece meal knee jack reforms/reactions that have since independence characterized the police service.

\section{References}

[1] Achieng' J. (1998) "Cleaning Up the Image of the Police" Inter Press Service, December 22

[2] Ajulu, R.(2002):“Politicized Ethnicity, Competitive Politics and Conflict in Kenya: A Historical Perspective." African Studies 61, no.2 251-68.

[3] Alston, Philip.(2009) "Statement by Professor Philip Alston, Special Rapporteur on extrajudicial, summary or arbitrary executions," delivered at the United Nations Human Rights Council

http://www.un.org/webcast/unhrc/11th/statements/Alston_S TMT.pdf

[4] Anderson, M (2002) Vigilantes, Violence and the Politics of Public Order in Kenya, African Affairs, 101 (405), pp.531555

[5] Auerbach N (2003) Police Accountability in Kenya: Seize the Moment, Commonwealth Human rights Initiative. Ed, Police as a Service Organization: An Agenda for Change. New Delhi, pp. $1-30$

[6] Bradbury, Mark and Kleinman, Michael (2010). Winning Hearts and Minds? Examining the Relationship Between Aid and Security in Kenya. Boston: Feinstein International Centre Tufts University

[7] Bristow, A.P. (1982) Rural Law Enforcement. Boston, MA: Allyn \& Bacon.
[8] Calas, B. (2008). From Rigging to Violence. Lafargue, J. (Ed.). The general elections in Kenya, 2007. (pp. 165-185). Dar es Salaam: Mkuki na Nyota Publishers, Ltd.

[9] E. Gimode (2001) An Anatomy of Violent Crime in Kenya: A Case of Nairobi: 1985- 1999: Africa Development Vol xx No 1 and 2001

[10] ---------. (2007) "The Role of the Police in Kenya's Democratization Process' in Godwin, R. Murunga and Shadrack, W. Nasong'o (Eds.), Kenya: The Struggle for Democracy. London: Zed Books, 227-60.

[11] Edgerton, R. B. (1989). MAU MAU: An African Crucible. New York: Ballantine Books.

[12] Erikson, R. and Haggerty, K. (1997) Policing the Risk Society, Buffalo, NY: University of Toronto Press.

[13] Foran R (1962) The Kenya Police:1887 - 1960. London, Robert Hale Limited

[14] Government of Kenya (2007). Kenya Vision 2030 Government Printers.

[15] Hills, A.(2011) Policing Africa: Internal Security and the Limits of Liberalization. London: Lynne Rienner. http://www.tandfonline.com/doi/pdf/10.1080/13600869.201 1.594659

[16] Human Rights Watch (2011),“Turning Pebbles” Evading Accountability for Post-Election Violence in Kenya",.

[17] ------------ (2008) Ballots to Bullets: Organized Political Violence and Kenya's Crisis of Governance. New York: Human Rights Watch.

[18] Human Rights Watch (2002) Playing with Fire: Weapons Proliferation, Political Violence and Human Rights in Kenya. New York: Human Rights Watch.

[19] Kamenju, Mwachofi and Wairagu (2003) Terrorized Citizen: Profiling Small Arms and Insecurity in the North Rift Region of Kenya, Security Research and Information Centre, Nairobi.

[20] Katumanga, M. (2005): “A City Under Siege: Banditry and Modes of Accumulations in Nairobi, 1991-2004." Review of African Political Economy 32, no. 106 :505-20.

[21] Kenya Police Service (2003) Kenya Police Service Strategic Plan 2003-2007 Draft 2. Nairobi: Kenya Police Service.

[22] ---------.(2008) Strategic Plan 2008-2012. Nairobi: Kenya Police Service.

[23] Leff, J. (2009) Pastoralists at War: Violence and Security in the Kenya-Sudan-Uganda Border Region. International Journal of Conflict and Violence. 3 (2): 188 - 203.

[24] Loader, I. (1996) Youth, Policing and Democracy, Basingstoke: Macmillan

[25] Mamdani, Mahmood. (1996) Citizen and Subject: Contemporary Africa and the legacy of Late Colonialism. London: James Currey.

[26] Mastrofski, S.Worden and Spines (1995) Systematic Observation of the Police. Washington, DC: NIJ.

[27] Muchai A (2003) Kenya Crime Survey 2003: Security Research and Information Centre 
[28] Muchai A (2002) Kenya Crime Survey 2002: Security Research and Information Centre

[29] Mutua, M. (2008). Kenya's Quest for Democracy: Taming the Leviathan. London: Lynne Rienner Publishers.

[30] Murunga, R. G. (2005): "Conflict in Somalia and Crime in Kenya: Understanding the Trans-Territoriality of Crime." African and Asian Studies 4, nos. 1-2 137-61.

[31] Mwaguri M and Oculli O (2006) Rethinking Global Security: An African Perspective: Heinrich Boll Foundation; Nairobi

[32] Mwenda, Albert. (2005) A Review of the Kenya Police Force Budget and its Effect on Crime Management. New Delhi: Matrix,
[33] National Task Force on Police Reforms (2009) Report of the National Task Force on Police Reforms, Nairobi. The Government Printer.

[34] Satterthwaithe,Margaret,(2007) "Rendered Meaningless: Extraordinary Rendition and the Rule of Law" 75 George Washington Law Review 1333

[35] The Police, The People, The Politics: Police Accountability in Kenya (2005); A Joint report by the Commonwealth Human Rights Initiative and Kenya National Human Right Commission 